\title{
sciendo
}

\section{Sensitive bioindicator plants studies, under the environmental conditions of climate change impact}

\author{
Andreea COZEA \\ National Research and Development Institute for Industrial Ecology INCD ECOIND, 71-73 \\ Drumul Podu Dambovitei Street, code 060652, Bucharest, Romania \\ andreea.cozea@yahoo.com \\ Gheorghe-Cosmin MANEA \\ Bucharest University of Economic Studies-E.A.I., TacheIonescu Street, Postal code 52632, \\ Bucharest, Romania \\ maneacosmin37@gmail.com \\ Elena BUCUR \\ National Research and Development Institute for Industrial Ecology INCD ECOIND, 71-73 \\ Drumul Podu Dambovitei Street, code 060652, Bucharest, Romania \\ poluare.aer@incdecoind.ro \\ Gina Alina CATRINA (Traistaru) \\ National Research and Development Institute for Industrial Ecology INCD ECOIND, 71-73 \\ Drumul Podu Dambovitei Street, code 060652, Bucharest, Romania \\ gina.catrina@incdecoind.ro
}

\begin{abstract}
Air pollution is a serious problem in many heavily populated and industrialized areas in the world. It affects vegetation, and also human health. The diversification of emission sources, among them vehicles, industrial processes, waste burnings and fuel storage, creates zones with different species and concentrations of air pollutants. In this paper was studied the excessive accumulation of toxic metals such as $\mathrm{Al}, \mathrm{Cr}, \mathrm{Ni}, \mathrm{Zn}, \mathrm{Pb}$ in vegetation as a risk factor for ecosystem and also for human health. The purpose of the study was to establish an optimal method of determination for toxic elements accumulation in leaves, using Inductively Coupled Plasma Mass Spectrometry (ICP-MS). These results made to suppose that, visible and analyzed responses of in in-situ exposed bio monitors compared with heavy metal accumulation depended on the atmospheric situation during the period of exposure, which could assess the efficiency of biomonitoring programs in the region. The advantage of this study consists in new and appropriate approach using a friendly methodology for air monitoring and favoring the development of a circular and sustainable economy.
\end{abstract}

Keywords: climate change impact, air pollution, heavy metals, bio indicators, sustainable economy

\section{Introduction}

Despite general efforts to protect the environment, air pollution continues to exceed the limits and values of the European Union and World Health Organization guidelines, according to updated data and information published by the European Environment Agency (EEA). Air pollution still poses a danger effect to human health and the environment. Emissions from industry contribute greatly to air pollution (www.eea.europa.eu). 
While there are many different types of pollution, industrial pollution refers explicitly to any contamination caused by industrial activities. Industrial pollution is a big issue because most pollution is caused by some industry, making it the most significant form of pollution on the planet.

The effects of industrial pollution are vast, causing water contamination, a release of toxins into soil and the air, and it is the cause of some of the most significant environmental disasters of all time.

Air pollution has been the culprit for many illnesses, increasingly frequent over time. The effects of air pollution have an impact on everyone, every day. Also, it affects vegetation, and also human health (Lewtas, 2007). The air is fundamental and essential for living beings but epidemiological studies provide evidences of the harmful impacts of air pollution by increased cardiopulmonary morbidity and mortality as well as reproductive disorders and cancers (Pope et al., 2002).

After realizing the existence of the danger of imbalance of the ecosystems that support life, it was sought to find ways to monitor the air pollution, by instrumental methods, by biomonitoring or combined assessment. This study aim was the air quality biomonitoring by exposing biological indicators in the affected ecosystems, results that could provide us with useful information on the environmental strategies that can be applied in monitored zones in order to improve the situation in the area (Barnett \& Naylor, 1966). The tests were performed in industrial and/or urban areas, being carried out in series of biological indicators in order to facilitate the detection of the specific effects of the action of atmospheric pollutants on the plants.

The aim was to study the reaction and the response of the two biosystems to the global change of the environment, which remains a reality, despite the international efforts that have begun to be made to achieve a sustainable development, which implies simultaneously the conservation of the environment.

The purpose of this supervision is represented, first of all, by the early detection of possible changes in the functioning and the component of the biological systems, which could eventually lead them to disorganization, collapse, or they could engage in an unfavourable evolution direction. Also were established optimal method of determination for toxic elements accumulation in leaves, using Inductively Coupled Plasma Mass Spectrometry (ICP-MS). The early warning of the specialists gives the possibility of the decision makers to take measures to remedy the situation, before the irreversible negative effects appear (Beg \& Farooq, 1988).

The inclusion of air biomonitoring in the monitoring system is justified by the importance of the climatic factors in carrying out complex biological processes. It is obvious that an integrated monitoring system requires the participation of a strong biological component in order to provide the most comprehensive information. In the environmental context, biological monitoring refers to the collection of information on the "health status" of biological organisms in order to evaluate the quality status of the environment (Budhraja \& Agarwal, 1993).

Bioindicators open a broad field of research; ongoing and ongoing, because there are still many issues to clarify and it is necessary to develop coherent methods of environmental monitoring through bio-indicators. In order for it to be used in a concrete way, in practice, species capable of providing the information necessary for the purpose pursued by monitoring and whose relations with environmental factors and other species in biocenosis must be selected. 


\section{Literature review}

After realizing the existence of the danger of unbalancing the ecosystems that sustain life throughout the planet, it was sought to find ways to supervise them.

The purpose of this surveillance was, first of all, the detection of possible changes in the functioning and composition of biological systems, which could eventually lead to disorganization, collapse, or could involve them in an unfavorable evolution direction. Early warning of specialists gives decision makers the opportunity to take measures to remedy the situation, before irreversible negative effects occur.

Secondly, the aim of the study was to correlate the reaction and the response of the biosystems to the global changes of the environment, which remains a reality, despite the international efforts that have begun to be made to achieve a sustainable development, which implies the conservation of the environment. The information obtained from the surveillance systems is stored in databases, in order to allow comparisons over time.

Globally there are several networks for monitoring the ecosystems. These networks have varying size and extension and are equipped with more or less sophisticated equipment. The largest network of ecosystems monitoring is in Europe. (Rose et. al., 2017)

\section{Methodology \\ „In-situ” experiments}

The "in-situ" experiments involved two distinct stages:

-Testing the sensitivity/tolerance of the three plant types in the context of air pollution in the industrial area $(\mathrm{A})$;

-Information and correlation on the response of the bioindicators tested to the action of the air pollution context in the two areas: industrial and urban (B);

Two case studies were conducted in this research stage: the first of the studies concerned an urban area with intense road traffic located in the Bucharest City Center, the area, and the second was organized in an industrial area, respectively neighbourhood of Oltchim Râmnicu Vâlcea.

For the "in-situ" experiments, the three species of plants were exposed to the action of air pollutants, namely Nicotiana tabacum (P1), Nicotiana rustica (P2) and Nicotiana alata (P3) and controls corresponding (M1, M2, M3) kept for comparison in the laboratory in controlled conditions. The duration of the exposure was 14 days in the July-August 2019 period; for each case study, six plants of each type were exposed. Both the exposed plants and the corresponding controls were planted in identical pots, in the same soil type being ensured the same conditions of exposure and watering (Muir \& McCune, 1987). The plants were maintained under laboratory conditions from sowing until they reached the exposure level (Figure 1, a, b) when they were transferred to each site. The leaf samples were collected at the end of the exposure period (Gaikwad et. al., 2006).

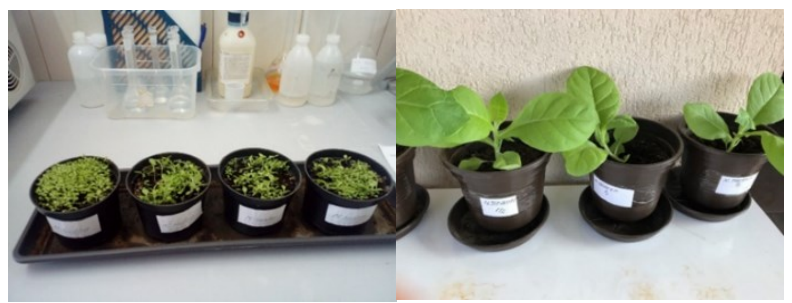

Figure 1. Plants used in various phases of development.

Source: Authors' own research. 
In order to interpret the response of the bioindicators tested to the action of the air pollution context in the two zones, industrial and urban, after exposure, leaf samples were collected and analysed in order to determine the degree of foliar destruction (Figure 2) in response to the environmental action on the plant (Kamalakar, 1992).

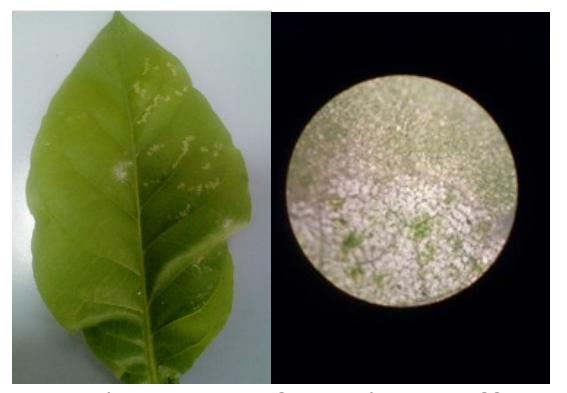

PICBE $\mid 53$

Figure 2: Microscopic aspect of the tissue affected by pollution

Source: Authors' own research.

For the assessment of the tolerance and the adaptive characteristics of the three types of bioindicators to the dynamics of pollution in each area, the Air Pollution Tolerance Index (APTI) was calculated, according to the relationship proposed by Singh and Rao (Agbaire, 2009).

$$
\mathrm{APTI}=\frac{\mathrm{A}(\mathrm{T}+\mathrm{P})+\mathrm{R}}{10}
$$

in which:

$\mathrm{A}=$ content in ascorbic acid, $\mathrm{mg} / 100 \mathrm{~g}$;

$\mathrm{T}=$ total chlorophyll content, $\mathrm{mg} / 100 \mathrm{~g}$;

$\mathrm{P}=\mathrm{pH}$ of the leaf extract;

$\mathrm{R}=$ relative content in water, $\%$;

Inductively Coupled Plasma Mass Spectrometry (ICP-MS) is a type of mass spectrometry that uses an Inductively coupled plasma to ionize the sample. It atomizes the sample and creates atomic and small polyatomic ions, which are then detected. It is known and used for its ability to detect metals and several non-metals in liquid samples at very low concentrations.

For the mineralization of samples in a closed system (microwave) was used a Milestone Up Ethos equipment (Kim et. al., 2015).

\section{Results and discussions}

For each type of plant, average/period samples were collected by harvesting and homogenizing the leaves from all the exposed plants and determining the 4 indicators needed to calculate the tolerance index. The results of these determinations and the calculated value of APTI for each type of plant and samples exposed area are presented in Table 1:

Table 1. Air Pollution Tolerance Index (APTI) results

\begin{tabular}{|l|l|l|l|l|l|}
\hline Sample & $\begin{array}{l}\text { Total } \\
\text { chlorophyll, } \\
\text { mg/100g }\end{array}$ & $\mathbf{p H}$ & $\begin{array}{l}\text { Ascorbic } \\
\text { acid, mg/100 } \\
\text { g }\end{array}$ & $\begin{array}{l}\text { Water } \\
\text { loss \% }\end{array}$ & APTI \\
\hline PI-1 & 7.74 & 7.2 & 6.95 & 59 & 16.3 \\
\hline PI-2 & 9.52 & 7.3 & 6.97 & 69 & 18.6 \\
\hline PI-3 & 13.15 & 8.5 & 4.95 & 68 & 17.5 \\
\hline M1 & 8.55 & 8.9 & 3.67 & 72 & 13.6 \\
\hline
\end{tabular}




\begin{tabular}{|l|l|l|l|l|l|}
\hline M2 & 14.69 & 8.7 & 5.63 & 78 & 21.0 \\
\hline M3 & 16.59 & 9 & 5.42 & 64 & 20.3 \\
\hline
\end{tabular}

To assess the degree of tolerance, the APTI results were compared with the sensitivity scale presented in Table 2.

PICBE | 54

Table 2. APTI scale

\begin{tabular}{|c|c|c|c|c|}
\hline & High sensitivity & Sensitivity & $\begin{array}{l}\text { Intermediary } \\
\text { sensitivity }\end{array}$ & Tolerant \\
\hline APTI Value & 1 & $1-16$ & $17-29$ & $30-100$ \\
\hline
\end{tabular}

Source:semanticscholar.org/paper/Evaluation-of-Air-Pollution-Tolerance-Index-(APTI)-Sharma-Sharma

It was found that, according to the APTI values, the sample P1 (Nicotiana tabacum) shows the highest sensitivity, samples at P2 (Nicotiana rustica) and P3 (Nicotiana alata) falling within the field of intermediate sensitivity; studies in the field, but also our results show the inverse correlation between the APTI value and the content of ascorbic acid, respectively by the direct correlation between the value of ATPI and the tolerance of the bioindicators to the environment; In these conditions, for the comparison between different types of plants, only the ascorbic acid content indicator can be used (Mignanego et. al., 1992).

It has thus been found that plants with high ascorbic acid content are more tolerant and can protect their physiological and molecular functioning even under stress (Noor et. al., 2015). As it is known, ascorbic acid is the most abundant antioxidant in plants and serves as a major contributor to cellular redox status. It was also observed that when the chlorophyll values decreased the ascorbic acid values increased (Miller, 1989).

The results of the sensitivity/tolerance tests thus revealed that all three types of plants can be used as bioindicators for air quality in the tested area. Considering the fact that in terms of air quality in the two areas presented in Table 3, the differences regarding average gas composition/period we consider to extend this assessment also on the urban area, where only the effect tests were performed on plants.

Table 3. Air quality in the tested areas

\begin{tabular}{|l|l|l|l|l|}
\hline & $\begin{array}{l}\mathbf{C O}, \\
\left(\boldsymbol{\mu g} / \mathbf{m}^{3}\right)\end{array}$ & $\begin{array}{l}\mathbf{N O}_{2}, \\
\left(\mu g / \mathbf{m}^{3}\right)\end{array}$ & $\begin{array}{l}\mathbf{S O}_{2}, \\
\left(\mu \boldsymbol{g} / \mathbf{m}^{3}\right)\end{array}$ & $\begin{array}{l}\mathbf{P M 1 0 ,} \\
\left(\boldsymbol{\mu g} / \mathbf{m}^{3}\right)\end{array}$ \\
\hline Industrial zone & 6.7 & 126 & 63 & 32 \\
\hline Urban zone & 7.8 & 144 & 87 & 52 \\
\hline 24 hours, limit value & 10 & 200 & 125 & 50 \\
\hline
\end{tabular}

Source: Authors' own research.

In Table no. 4 are summarized the foliar changes observed in the plants exposed in the two tested areas. 
We can thus observe that if in the case of Nicotiana rustica (P2) the degree of foliar destruction is the same, for the other two types of plants it is higher in the industrial area than in the urban area and higher for the Nicotiana alata (P3) compared to the other two types of plants.

In Table no. 4 are presented the foliar changes observed in the plants exposed in the two tested area.

PICBE $\mid 55$

Table 4. the foliar changes observed in the plants exposed in the tested area

\begin{tabular}{|l|l|}
\hline Industrial area & Urban area \\
\hline $\begin{array}{l}\text { Oversized development of plants, but having a } \\
\text { generally fragile appearance compared to control } \\
\text { plants; }\end{array}$ & $\begin{array}{l}\text { Atrophies - are reductions in the normal size of some } \\
\text { organs of the plant or even of the plant }\end{array}$ \\
\hline $\begin{array}{l}\text { Decolorization of the foliar surface and the appearance } \\
\text { of chlorotic spots - a consequence of air pollution; }\end{array}$ & It has no typical symptoms of necrosis or chlorosis; \\
\hline $\begin{array}{l}\text { Increasing the number of stomata and reducing their } \\
\text { size as an effect of adapting the plant to gas exchange; }\end{array}$ & $\begin{array}{l}\text { No visible damage on the leaves, but suppresses their } \\
\text { growth and shrinking foliage surface; }\end{array}$ \\
\hline $\begin{array}{l}\text { The decrease in the thickness of the mesophyll, hence } \\
\text { the correspondence in the fragile aspect of the exposed } \\
\text { plants; }\end{array}$ & \\
\hline
\end{tabular}

Source: Authors' own research.

In Table 5 are presented the results of the elemental analysis for the three types of bioindicators exposed and controls in the two tested areas reported $\%$ on dry substance.

Table 5. The results of the elemental analysis for the three types of bioindicators exposed and controls

\begin{tabular}{|l|l|l|l|}
\hline Sample & C \% & H\% & N \% \\
\hline M-1 & 40.97 & 4.77 & 1.71 \\
\hline M-2 & 33.74 & 3.69 & 2.26 \\
\hline M-3 & 33.71 & 3.38 & 1.80 \\
\hline PU-1 & 34.93 & 3.95 & 6.47 \\
\hline PU-2 & 33.09 & 3.87 & 5.32 \\
\hline PU-3 & 34.24 & 4.25 & 6.94 \\
\hline PI-1 & 30.17 & 3.84 & 7.01 \\
\hline PI-2 & 29.38 & 3.87 & 6.20 \\
\hline PI-3 & 29.39 & 3.84 & 6.22 \\
\hline
\end{tabular}

Source: Authors' own research. M - Bioindicators Control; PU- Bioindicators Samples exposed in the Urban area; PI- Bioindicators Samples exposed in the Industrial area; 1-Nicotiana tabacum; 2-Nicotiana rustica; 3-Nicotiana alata;

Additional information provided by analysis shows large differences in $\mathrm{N}$ content between the exposed plants and the control plants, indicating these element as possible indicators of air quality in the accumulation biomonitoring (Kim et. al., 2019).

Based on the results obtained, we can observe a destructive effect of the air composition on the plants used as bio indicators, which can raise question marks regarding the effect on the health of the population in these areas and the need to implement measures to reduce pollution (Rao,1979; Rao \& Dubey, 1992). We can also appreciate the usefulness of these plants as indicators of air pollution cheap and easy to obtain (Singh,1993). 
Also, by conducting these case studies, the method of biomonitoring of air quality developed in previous studies was verified.

Also, additional information provided the elementary analysis (Table 5.); large differences can be observed between the content of $\mathrm{N}$ and metals between exposed plants and control plants, indicating these elements as possible indicators of air quality in the accumulation biomonitoring.

Table 6The results of the elemental analysis for the three types of bioindicators exposed PICBE | 56 and controls in the two tested areas on dry substance.

Table 6. The results of the elemental analysis for the three types of bioindicators exposed and controls

\begin{tabular}{|c|c|c|c|c|c|}
\hline Samples & $\begin{array}{l}A l \\
(m g / k g \text { d.s. })\end{array}$ & $\begin{array}{l}C r \\
(m g / k g \text { d.s. })\end{array}$ & $\begin{array}{l}N i \\
(m g / k g \text { d.s. })\end{array}$ & $\begin{array}{l}Z n \\
(m g / k g \text { d.s. })\end{array}$ & $\begin{array}{l}P b \\
(m g / k g \text { d.s. })\end{array}$ \\
\hline M-1 & 64.11 & 0.90 & 2.75 & 39.39 & 0.42 \\
\hline M-2 & 62.96 & 0.84 & 2.69 & 90.18 & 0.33 \\
\hline M-3 & 61.97 & 0.89 & 2.73 & 38.81 & 0.40 \\
\hline PU-1 & 254.06 & 1.93 & 7.83 & 93.69 & 1.42 \\
\hline PU-2 & 233.39 & 1.01 & 4.95 & 133.57 & 1.34 \\
\hline PU-3 & 318.90 & 3.04 & 25.54 & 101.58 & 2.02 \\
\hline PI-1 & 630.08 & 5.96 & 70.72 & 95.46 & 3.29 \\
\hline PI-2 & 374.52 & 1.99 & 9.56 & 171.05 & 2.03 \\
\hline PI-3 & 696.47 & 3.81 & 35.90 & 124.84 & 2.54 \\
\hline
\end{tabular}

Source: Authors' own research.

M- Control Bioindicators; PU- Bioindicators exposed in the Urban area; PI - Bioindicators exposed in the Industrial area;

1-Nicotiana tabacum, 2- Nicotiana rustica, 3- Nicotiana alata;

From these results were obtained the following: the most significant values regarding the bioaccumulation capacity of the tested plants were noted at those exposed in the Industrial Zone, in the case of aluminum content high values of $660.08 \mathrm{mg} / \mathrm{kg}$ were obtained at PI-1 (Nicotiana tabacum) compared to the average values obtained mainly for the plants exposed in the PU Urban Area of $254.06-318.90 \mathrm{mg} / \mathrm{kg}$ and small values for the control plants of $61.97 \mathrm{mg} / \mathrm{kg}$ (Nicotiana alata). For the chromium content high values were obtained for the Industrial Zone $5.97 \mathrm{mg} / \mathrm{kg}$ (Nicotiana tabacum), average values obtained both in the Industrial Zone and in the Urban PI-3 of $3.81 \mathrm{mg} / \mathrm{kg}$ su and PU-3 of $3.04 \mathrm{mg} / \mathrm{kg}$ su compared with the small values obtained in control plants M-2 of $0.84 \mathrm{mg} / \mathrm{kg}$. Regarding the accumulation of nickel were observed for the plants exposed in the Industrial Zone, PI-1 values of $70.72 \mathrm{mg} / \mathrm{kg}$, compared to the average values reduced by half of $25-35 \mathrm{mg} / \mathrm{kg}$ observed in plants exposed both in the Industrial Zone as well as urban and comparative with the values at the control of $2.69 \mathrm{mg} / \mathrm{kg} \mathrm{M} 2$ (Nicotiana rustica). The zinc content recorded increased values at PI-2 (Nicotiana rustica) $171.05 \mathrm{mg} / \mathrm{kg}$, average values of $133.57 \mathrm{mg} / \mathrm{kg}$ (PU-2) compared with the low values of $38.81 \mathrm{mg} / \mathrm{kg}$ at M 3. The lead content recorded values of $3.29 \mathrm{mg} / \mathrm{kg}$ in the Industrial Zone (PI-1) compared to those obtained in the control plants of $0.33 \mathrm{mg} / \mathrm{kg}$. From these obvious results obtained was concluded that the plants selected as bioindicator can be successfully used as bioaccumulators in air biomonitoring studies.

\section{Conclusion}

Based on the obtained results, a destructive effect of the air composition on the plants used as bioindicators could be observed, which can raise question marks regarding the effect on the health 
of the population in these areas and the need to implement measures to reduce pollution. We can also appreciate the usefulness of these plants as indicators of air pollution cheap and easy to obtain. - Based on the case studies of "in-situ" exposure, we appreciate that the previously developed biomonitoring method should be used successfully in the case studies aimed at evaluating ambient air quality;

- The value of the APTI index - provided conclusive information regarding the degree of sensitivity / tolerance of bioindicators in the environment;

The bioindicators tested have demonstrated bioaccumulation properties and can be used in the accumulation biomonitoring studies.

\section{References}

Agbaire, P. O. (2009) Air pollution tolerance indices (APTI) of some plants around erhoikekokori oil exploration site of delta state, Nigeria. Int J Phys Sci Int J Physical Sci, 4(6), 25-32.

Barnett, N. M. \& Naylor A.W. (1966). Amino acid and protein metabolism in Bermuda grass during water strees. Plant Physiology, 1222-1230.

Beg M. U. \& Farooq M. (1988). Sulphur dioxide resistance of Indian trees. Water, Air and Soil Pollution, 317-328.

Budhraja, A. \& Agarwal, S.K. (1993). Air pollution tolerance indices of some planted trees in urban area of kota with references to automobile pollution. Acta Ecol., 15 (1), 62-72.

Ecol. Lett., 20 (2), 147-157

Gaikwad, U. S. Ranade C.D. \& Gadgil, J.M. (2006). Plants as bio-indicators of automobile exhaust pollution-A case study of Sangli City. J Institution Engineers (India), Environ Engineering Division, 8.

https://www.eea.europa.eu/en/highlights/

J. A. Kamalakar, (1992) Response of plants to auto exhaust pollution. Acta Botanica Indica, 20, 84-88.

Kim, L., Catrina (Traistaru), G. A., Stanescu, B., Pascu, L. Fl., Gheorghita, T., \& Manolache, D. (2019). The Chemical Fractions and Leaching of Heavy Metals in Ash from Medical Waste Incineration using Two Different Sequential Extraction Procedures, Rev. Chim. (Bucharest), 70(1), 286-292.

Kim, L., Vasile, G., Stanescu, B., Calinescu, S., \& Batrinescu G. (2015). Distribution and bioavailability of mobile arsenic in sediments from a mining catchment area. Journal of Environmental Protection and Ecology 16(4),1227-1236.

Lewtas, J. (2007). Air pollution combustion emissions: characterization of causative agents and mechanisms associated with cancer, reproductive, and cardiovascular effects, Mutation Research, 636(1-3), 95-133.

Mignanego, L., Biondi, F., \& Schenone, G. (1992). Ozone biomonitoring in northern Italy. Environmental Monitoring and Assessment, 21(2), 141.

Miller, P. R. (1989). Biomarkers for defining air pollution effects in western coniferous forests. In: Biologic markers of air pollution stress and damage in forests, Committee on biological markers of air pollution damage in trees, National Research Council, National Academy Press, Washington.

Muir D. C. \& McCune, B. (1987). Index construction for foliar symptoms of air pollution injury. Phytopathology, 71, 558-565.

Noor, M. J. Sultana, S. Fatima, S. Ahmad, M. Zafar, M. \& Sarfraz, M. (2015). Estimation of anticipated performance index and air pollution tolerance index and of vegetation around the marble industrial areas of pot war region: bioindicators of plant pollution response. Environ Geochem Health; 37(3). 
Pope, C.A., Burnett, R.T., Thun, M.J., Calle, E.E., Krewski, D., Ito, K. \& Thurston, G.D. (2002). Lung cancer, cardiopulmonary mortality, and long-term exposure to fine particulate air pollution, JAMA, 287(9), 1132-1141.

Rao, D. N. (1979). Plant leaf as pollution monitoring device. Fertilizer News.

Rao, M.V. \& Dubey P.S, (1992). Occurrence of heavy metals in air and their accumulation by tropical plants growing around industrial areas. Science of the total Environment, 126.

Rose, K.C., Graves, R.A., Hansen, W.D., Harvey, B.J., Qiu, J., Wood, S.A., Ziter, C., \& Turner M.G. (2017). Historical foundations and future directions in macrosystems ecology

Singh, S. K. (1993). Phytomonitoring of urban-industrial pollutants: a new approach, Environ Monit Assess; 24 (1), 27-34. 